\title{
Comparative Effect of Valsartan and Amlodipine on Insulin Resistance in Hypertensive Patients
}

\author{
Dr. Musab M Khalaf \\ Department of Pharmacology and Toxicology, College of Pharmacy, University of Mosul, Mosul, Iraq. \\ Correspondence:. musabm813@gmail.com.
}

(Ann Coll Med Mosul 2019; 41 (1):52-56).

Received: $17^{\text {th }}$ Feb. 2019; Accepted: $15^{\text {th }}$ May 2019.

\begin{abstract}
Objectives: To study the effect of commonly used first line antihypertensive drugs valsartan and amlodipine on insulin resistance parameters in hypertensive patients free from type 2 diabetes mellitus.

Patients and methods: In a prospective, randomized study, 32 non-diabetic patients with mild to moderate hypertension attending private clinics in Mosul city were recruited. The patients were randomized into two treatment groups to receive either amlodipine in the dose range of 5-10 mg daily or valsartan in the dose range of $80-160 \mathrm{mg}$ daily. At baseline and 8 weeks of treatment fasting serum glucose (FSG), fasting serum insulin (FSI), homeostasis model assessment for insulin resistance (HOMA-IR), mean systolic and diastolic blood pressures levels were determined.

Results: Intragroup comparison showed that after 8 week treatment with amlodipine and valsartan, SBP, DBP, FSI and HOMA-IR for both groups were significantly decreased in comparison with baseline data while FSG where non significantly decreased. Valsartan reduce SBP, FSG, FSI and HOMA-IR more than amlodipine but this reduction was not statistically significant.

Conclusion: This study showed that the antihypertensive drugs amlodipine and valsartan have favorable effects on insulin resistance mediated by decreasing HOMA-IR in non-diabetic hypertensive patients. Also, this study illustrated that valsartan seems to have a more potent effect of lowering HOMA-IR than amlodipine in the standard dose.
\end{abstract}

Keyword: Valsartan, amlodipine, hypertension, insulin resistance.

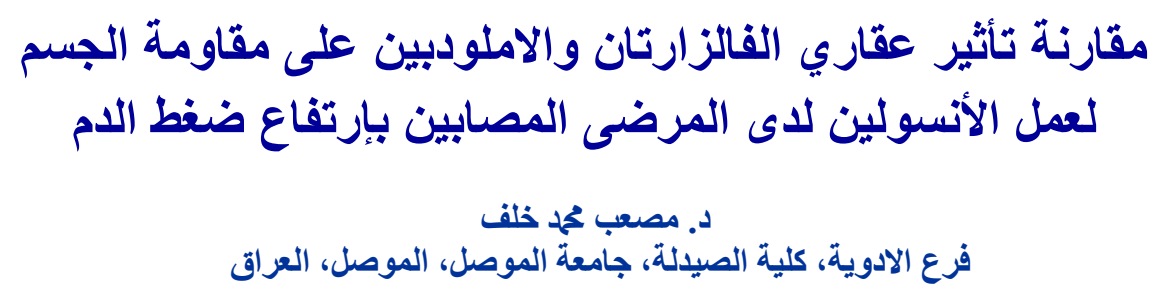

الخلاصة

الهُف من الاراسة: دراسة تأثثر أدوية إرتفاع ضغط الدم الثائعة الإستعمال مثل عقاري الفالزارتان و الاملودبين على مقاومة الجسم لعمل الأنسولين لدى مرضى ضغط الدام غير المصابين بداء السكري من النوع الثناني. التصميم: دراسة مستقبلية عشو ائية التقسيم. لأنسئ

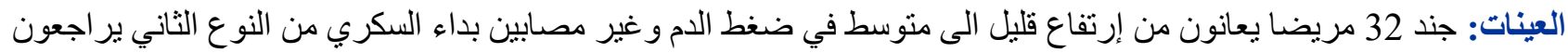

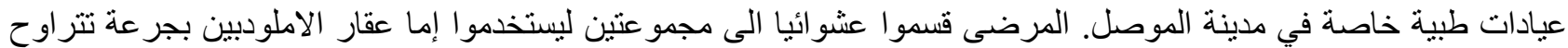

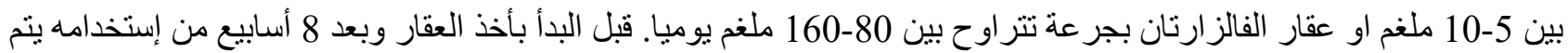

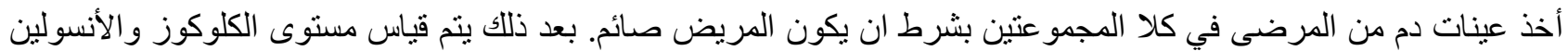
في مصل الدم وحساب تقييم نموذج الإتزان لمقاومة الأنسولين (HOMA-IR) وكذللك قياس ضغط الني الدم الإنقباضي و الإنبساطي. 
النتائج: عند إجر اء المقارنات بين المجموعات المختلفة بعد 8 أسابيع من العلاج بعقاري الاملودبين والفالزارتان، تبين أن ضغط الإنا

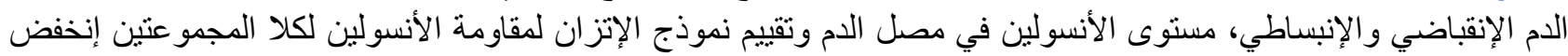

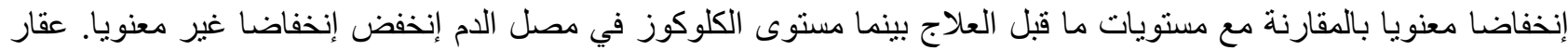

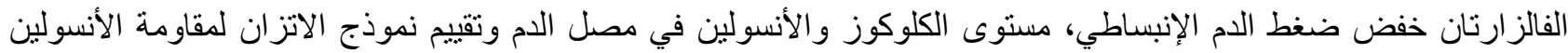

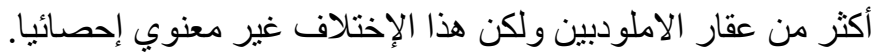

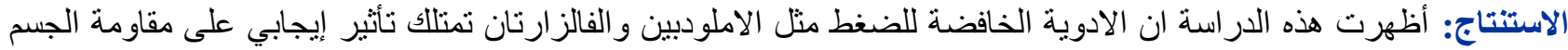

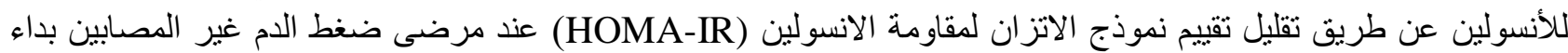

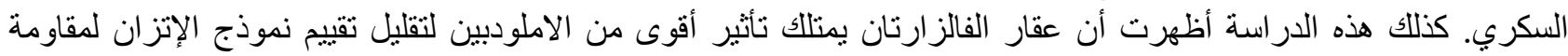
الأنسولين بإستخدام الجر عة القياسية. الكلمات المفتاحية: فالزارتان، أملودبين، إرتفاع ضغئة الإنغ الدم، مقاومة عمل الأنسولين.

\section{INTRODUCTION}

ypertension is the most widespread cardiovascular disease. Permanently elevated arterial blood pressure damages blood vessels in kidney, heart, and brain and leads to an increased incidence of renal failure, coronary disease, heart failure and stroke. Therefore, pharmacologic treatment of blood pressure has been shown to prevent damage to blood vessels and to substantially reduce morbidity and mortality rates ${ }^{1}$. The most commonly used drugs for the management of hypertension include, $\beta$ adrenoceptor blockers, diuretics, angiotensin converting enzyme inhibitors, angiotensin receptor blockers, calcium channel blockers, and others ${ }^{2}$.

Elevated blood pressure tends to impair glucose tolerance and induce a resistance to the actions of insulin rendering hypertensive patients at a risk of developing diabetes mellitus ${ }^{3}$. Non-treated patients with essential hypertension generally have higher fasting and postprandial insulin levels than normotensive patients. A direct relationship presents between blood pressure and fasting insulin levels in patients with essential hypertension ${ }^{4}$.

Many studies have shown that insulin resistance, which is present in more than $50 \%$ of the patients with hypertension ${ }^{5,6}$, plays an important role in the development and progression of hypertension and diabetes. In addition to its role in increasing the incidence of diabetes ${ }^{7}$, insulin resistance is also directly linked with the severity of hypertension ${ }^{5}$. Therefore, it is important that antihypertensive drugs are chosen such that they do not adversely affect the metabolic parameters and worsen the already insulin resistant state in hypertensive patients and rather prevent the new onset of diabetes mellitus in hypertensive patients ${ }^{8}$.

So the main objective of this study was to study the influence of commonly used first line antihypertensive drugs valsartan and amlodipine on insulin resistance parameters in hypertensive patients free from diabetes mellitus.

\section{METHODS}

Thirty two non-diabetic patients with mild to moderate hypertension between 25-55 year age male or female attending private medical clinics in Mosul city were recruited in this study from April 2018 to November 2018. The exclusion criteria includes any patient take other drugs except valsartan and amlodipine, patients with any type of diabetes, patients have secondary hypertension, patients with uncontrolled hypertension, patients with other disease states, and any hypersensitivity to valsartan and amlodipine.

The study was approved by the Medical Research and Ethics Committee of the Department of Pharmacology and Toxicology, College of Pharmacy, University of Mosul (Iraq). Before the beginning of the study, all participants given written informed consent.

This was a prospective, openlabled, randomized controlled study. The patients participatedy in the study were randomized into two groups to receive the following treatments orally: Group I (Amlodipine no=17): Amlodipine titrated from $5 \mathrm{mg}$ to $10 \mathrm{mg}$ daily, Group II (Valsartan no= 15): Valsartan titrated from $80 \mathrm{mg}$ to $160 \mathrm{mg}$ daily. Treatment with this drugs were continued for 8 week period. 
Five milliliters venous blood samples were obtained from both groups of treatment at baseline and after 8 week treatment after overnight fasting. Fasting serum insulin (FSI) was measured by the LIAISON insulin assay uses chemiluminescencev immunoassay (CLIA) technology for the in vitro quantitative determination of insulin in human serum specimens. DiaSorin S.p.A Via Crescentino snc-13040 Saluggia (VC) Italy. Fasting serum glucose (FSG) was measured by Trinder method (Trinder 1969) using Human Glucose GOD-PAP kit (BIOLABO SA, Maizy, France) ${ }^{9}$.

The homeostasis model assessment for insulin resistance (HOMA-IR) was computed as ${ }^{10}$ :

$$
H O M A-I R=\frac{F S I \mu I U \times F S G \mathrm{mmol} / L}{22.5}
$$

Body mass index was calculated using the formula:

$$
\mathrm{BMI}=\text { Weight in } \mathrm{Kg} /(\text { Height in } \mathrm{m})^{2}
$$

Mercury sphygmomanometer was used to record the blood pressure, systolic blood pressure (SBP) and diastolic blood pressure (DBP). Each patient was instructed to sit for at least five minutes in a chair before measuring blood pressure. The auscultatory method of blood pressure measurement was used. Mean of the two recordings was taken. Blood pressure was recorded for each patients both at baseline and after 8 week treatment.

The data in this study are expressed as mean $\pm S D$. $P$-value equal or less than 0.05 was considered significant in all types of statistical tests. The present study was analyzed using SPSS program (version 15). Unpaired t-test was used for the analyses between valsartan and amlodipine groups for the data at baseline and at 8 week. Paired t-test was used to compare the differences in various parameters of the hypertensive patients before and after therapy in each group.

\section{RESULTS}

Thirty two patients were recruited in this study and randomly divided into two groups to receive treatment with amlodipine $(n=17)$ or valsartan $(n=15)$ once daily for 8 weeks. The characteristics and baseline data of the study groups were shown in Table 1, there were no significant differences between the two groups in term of baseline data except for BMI (the difference was significant), and the study subjects were approximately comparable with each other for different demographic and clinical variables.

The results also showed that after 8 week treatment with amlodipine and valsartan, SBP, DBP, FSI and HOMA-IR for both groups were significantly decreased in comparison with baseline data while FSG where non significantly decreased as shown in Table 2 and $\mathbf{3}$.

Table 4 shows that valsartan produce nonsignificant greater reduction in SBP, FSG, FSI and HOMA-IR than amlodipine in terms of greater difference that its produce.

Table 1: Baseline characteristics for amlodipine and valsartan groups.

\begin{tabular}{lccc}
\hline Variables & $\begin{array}{l}\text { Valsartan } \\
\text { Mean } \pm \text { SD } \\
\text { No=15 }\end{array}$ & $\begin{array}{l}\text { Amlodipine } \\
\text { Mean } \pm \text { SD } \\
\text { No=17 }\end{array}$ & $\begin{array}{l}\boldsymbol{P} \text { - } \\
\text { value }\end{array}$ \\
\hline $\begin{array}{l}\text { Age (Year) } \\
\text { Gender } \\
\text { (Male/Female) }\end{array}$ & $39.18 \pm 7.84$ & $37.93 \pm 8.29$ & 0.6 \\
\hline BMI $\left(\mathrm{Kg} / \mathrm{m}^{2}\right)$ & $25.4 \pm 2.48$ & $28.7 \pm 1.99$ & $0.02^{*}$ \\
\hline SBP $(\mathrm{mmHg})$ & $161.17 \pm 8.39$ & $159.37 \pm 8.13$ & 0.5 \\
\hline DBP $(\mathrm{mmHg})$ & $99.11 \pm 7.12$ & $99.68 \pm 6.18$ & 0.8 \\
\hline FSG $(\mathrm{mmol} / \mathrm{L})$ & $4.40 \pm 1.06$ & $4.6 \pm 0.87$ & 0.5 \\
\hline FSI $(\mu \mathrm{IU} / \mathrm{ml})$ & $9.61 \pm 1.46$ & $10.2 \pm 2.23$ & 0.3 \\
\hline HOMA-IR & $1.87 \pm 0.54$ & $2.04 \pm 0.49$ & 0.3 \\
\hline
\end{tabular}

Unpaired t-test

${ }^{*}$ Significant differences

Table 2: Effect of valsartan on studied parameters after

\begin{tabular}{|c|c|c|c|c|}
\hline Variables & $\begin{array}{l}\text { Time } \\
\text { point }\end{array}$ & $\begin{array}{l}\text { Valsartan } \\
\text { No }=15\end{array}$ & $\begin{array}{l}\text { Difference } \\
\text { Mean } \pm S D\end{array}$ & $\begin{array}{l}P \text { - } \\
\text { value }\end{array}$ \\
\hline \multirow{2}{*}{$\begin{array}{l}\text { SBP } \\
(\mathrm{mmHg})\end{array}$} & Baseline & $161.17 \pm 8.39$ & \multirow{2}{*}{$\begin{array}{c}16.76 \pm \\
5.28\end{array}$} & \multirow{2}{*}{$0.0001^{*}$} \\
\hline & 8 week & $144.41 \pm 7.47$ & & \\
\hline \multirow{2}{*}{$\begin{array}{l}\text { DBP } \\
(\mathrm{mmHg})\end{array}$} & Baseline & $99.11 \pm 7.12$ & \multirow{2}{*}{$9.11 \pm 4.04$} & \multirow{2}{*}{$0.0001^{*}$} \\
\hline & 8 week & $90.0 \pm 5.59$ & & \\
\hline \multirow{2}{*}{$\begin{array}{l}\text { FSG } \\
(\mathrm{mmol} / \mathrm{L})\end{array}$} & Baseline & $4.40 \pm 1.06$ & \multirow{2}{*}{$0.16 \pm 0.41$} & \multirow{2}{*}{0.07} \\
\hline & 8 week & $4.24 \pm 0.91$ & & \\
\hline \multirow{2}{*}{$\begin{array}{l}\text { FSI } \\
(\mu \mathrm{lU} / \mathrm{ml})\end{array}$} & Baseline & $9.61 \pm 1.46$ & \multirow{2}{*}{$0.75 \pm 0.39$} & \multirow{2}{*}{$0.0001^{*}$} \\
\hline & 8 week & $8.86 \pm 1.3$ & & \\
\hline \multirow{2}{*}{$\begin{array}{l}\text { HOMA- } \\
\text { IR }\end{array}$} & Baseline & $1.87 \pm 0.54$ & \multirow{2}{*}{$0.20 \pm 0.19$} & \multirow{2}{*}{$0.001^{*}$} \\
\hline & 8 week & $1.67 \pm 0.45$ & & \\
\hline
\end{tabular}
8 week treatment.

Paired t-test

* Significant differences 
Table 3: Effect of amlodipine on studied parameters after 8 weeks treatment.

\begin{tabular}{|c|c|c|c|c|}
\hline Variables & $\begin{array}{l}\text { Time } \\
\text { point }\end{array}$ & $\begin{array}{l}\text { Amlodipine } \\
\text { No }=17\end{array}$ & $\begin{array}{l}\text { Difference } \\
\text { Mean } \pm S D\end{array}$ & $\begin{array}{l}P \text { - } \\
\text { value }\end{array}$ \\
\hline \multirow{2}{*}{$\begin{array}{l}\text { SBP } \\
(\mathrm{mmHg})\end{array}$} & Baseline & $159.37 \pm 8.13$ & \multirow{2}{*}{$15.93 \pm 7.12$} & \multirow{2}{*}{0.0001} \\
\hline & 8 week & $143.43 \pm 4.36$ & & \\
\hline \multirow{2}{*}{$\begin{array}{l}\text { DBP } \\
(\mathrm{mmHg})\end{array}$} & Baseline & $99.68 \pm 6.18$ & \multirow{2}{*}{$10 \pm 6.05$} & \multirow{2}{*}{0.0001} \\
\hline & 8 week & $89.68 \pm 4.64$ & & \\
\hline \multirow{2}{*}{$\begin{array}{l}\text { FSG } \\
(\mathrm{mmol} / \mathrm{L})\end{array}$} & Baseline & $4.60 \pm 0.87$ & \multirow{2}{*}{$0.13 \pm 0.37$} & \multirow{2}{*}{0.1} \\
\hline & 8 week & $4.46 \pm 0.77$ & & \\
\hline \multirow{2}{*}{$\begin{array}{l}\text { FSI } \\
(\mu \mathrm{lU} / \mathrm{ml})\end{array}$} & Baseline & $10.20 \pm 2.23$ & \multirow{2}{*}{$0.66 \pm 0.75$} & \multirow{2}{*}{$0.003^{*}$} \\
\hline & 8 week & $9.53 \pm 1.69$ & & \\
\hline \multirow{2}{*}{$\begin{array}{l}\text { HOMA- } \\
\text { IR }\end{array}$} & Baseline & $2.04 \pm 0.51$ & \multirow{2}{*}{$0.17 \pm 0.24$} & \multirow{2}{*}{$0.01^{*}$} \\
\hline & 8 week & $1.87 \pm 0.40$ & & \\
\hline
\end{tabular}

Table 4: Difference produce by amlodipine and valsartan.

\begin{tabular}{|c|c|c|c|}
\hline \multirow[b]{2}{*}{ Variables } & \multicolumn{2}{|c|}{ Difference } & \multirow{2}{*}{$\begin{array}{c}P \text { - } \\
\text { value }\end{array}$} \\
\hline & $\begin{array}{l}\text { Valsartan } \\
\text { No }=15\end{array}$ & $\begin{array}{c}\text { Amlodipine } \\
\text { No }=17\end{array}$ & \\
\hline $\begin{array}{l}\text { SBP } \\
(\mathrm{mmHg})\end{array}$ & $16.76 \pm 5.28$ & $15.93 \pm 7.12$ & 0.6 \\
\hline $\begin{array}{l}\text { DBP } \\
(\mathrm{mmHg})\end{array}$ & $9.11 \pm 4.04$ & $10 \pm 6.05$ & 0.8 \\
\hline $\begin{array}{l}\text { FSG } \\
(\mathrm{mmol} / \mathrm{L})\end{array}$ & $0.16 \pm 0.41$ & $0.13 \pm 0.37$ & 0.4 \\
\hline FSI $(\mu \mathrm{IU} / \mathrm{ml})$ & $0.75 \pm 0.39$ & $0.66 \pm 0.75$ & 0.2 \\
\hline HOMA-IR & $0.20 \pm 0.19$ & $0.17 \pm 0.24$ & 0.1 \\
\hline
\end{tabular}

Unpaired t-test

\section{DISCUSSION}

Diabetes occurring concomitantly with hypertension increases the risk of cardiovascular diseases by manifold ${ }^{11}$. Several studies showed the insulin sensitizing effects of ARBs especially telmisartan. Telmisartan has an action similar to the thiazolidinedione drugs which possess agonistic activity at peroxisome proliferatoractivated receptor, gamma (PPAR-y), this explains its effects on glucose- insulin metabolism ${ }^{12}$. But it is not known if this favorable effect on insulin sensitivity is shared by whole ARB class or not.

Other clinical studies have shown that amlodipine, the long acting calcium channel blockers may improve glucose tolerance and lower insulin resistance ${ }^{13}$. Therefore, this study was conducted to evaluate improvements of insulin resistance and elevated blood pressure in patients with hypertension receive treatment with either amlodipine or valsartan for 8 weeks.

The results of this study demonstrated that in non-diabetic hypertensive patients, both studied drugs exhibited favorable effects on the glucometabolic variables and blood pressure (significant decrease in FSI, HOMA-IR, SDP and DBP but non-significant decrease in FSG).

In a study conducted by Bharati and Singh, 2016 who studied the effects of two antihypertensive drugs losartan (50-100) $\mathrm{mg}$ and amlodipine (5-10) $\mathrm{mg}$ in 40 nondiabetic hypertensive patients, they concluded that losartan and amlodipine lowered insulin resistance $(P<0.05)$ in patients of mild to moderate hypertension ${ }^{14}$.

Tian et al., 2016 in their meta-analysis about the effect of valsartan on insulin resistance in patients with hypertension found that many clinical studies have reported that valsartan was effective at lowering blood pressure and improving insulin resistance in patients with hypertension ${ }^{15}$.

Of the two drugs in this study, valsartan produce greater reduction in HOMA-IR than amlodipine but the difference was not statistically significant and this was in agreement with the results of the Tian et al., 2016 who stated that "The present metaanalysis suggested that valsartan showed a tendency to be superior to other antihypertensive drugs in the improvement of insulin resistance" ${ }^{15}$.

In two studies, it has been reported that the angiotensin (AT1) receptor blocker telmisartan and the ACE inhibitor ramipril also have antidiabetic effects mediated by stimulation of the peroxisome proliferator-activated receptor-gamma (PPAR- $\gamma$ ) receptor and probable benefits to insulin sensitivity 16,17

Calcium channel blockers (CCBs) may decrease insulin resistance by having vasodilator action especially in the insulin sensitive tissues with negligible increase in sympathetic activity. Calcium channel blockers may help in the translocation of glucose transporters and prevent the inhibition of glycogen synthase by calcium. Improvement in insulin sensitivity by CCBs might be linked through their antioxidant effects ${ }^{18}$.

The possible mechanisms by which ARBs may improve the insulin resistance are hemodynamic effects, increase of glucose transport and improvement of the intracellular signal transduction of insulin ${ }^{19,20}$. Furthermore, these effects may be 
due to blocking the oxidative stress and the reduction of adiponectin level ${ }^{21}$. Telmisartan and irbesartan have a partial agonist action of PPARY ${ }^{22}$ and are expected to have beneficial effects on insulin resistance by increasing adiponectin levels than the other ARBs without such action.

\section{CONCLUSION}

This study showed that the antihypertensive drugs amlodipine and valsartan have favorable effects on insulin resistance mediated by decreasing HOMAIR in non-diabetic hypertensive patients. Also, this study illustrated that valsartan seems to have a more potent effect of lowering HOMA-IR than amlodipine in the standard dose.

\section{REFERENCES}

1. Benowitz NL. Antihypertensive agents. In: Basic and Clinical Pharmacology. Katzung BG, editor. $14^{\text {th }}$ edition. McGraw Hill. 2018; p 173.

2. Dyker AG. Hypertension. In: Clinical Pharmacy and Therapeutics. Walker R, Whittlesea $\mathrm{C}$, editor. $5^{\text {th }}$ edition. Churchill Livingstone. 2012; p 295-311.

3. Taylor EN, Hu FB, Curhan GC. Antihypertensive medications and the risk of incident type 2 diabetes. Diabetes Care. 2006;29(5):1065-70.

4. Sowers JR. Insulin resistance and hypertension. Am J Physiol Heart Circb Physiol. 2004;286:H1597-H1602.

5. Ferrannini E, Buzzigoli G, Bonadonna R, et al. Insulin resistance in essential hypertension. $\mathrm{N}$ Engl $\mathrm{J}$ Med. 1987; 317: 350-357.

6. Shen DC, Shieh SM, Fuh MM, et al. Resistance to insulin-stimulated-glucose uptake in patients with hypertension. J Clin Endocrinol Metab. 1988; 66: 580583.

7. Yoshida M, Tomiyama $\mathrm{H}$, Yamada $J$, et al. Relationship of insulin resistance to macro- and microvasculature reactivity in hypertension. Am J Hypertens. 2010; 23: 495-500.

8. Fukao K, Shimada K, Hiki M, et al. Effects of calcium channel blockers on glucose tolerance, inflammatory state, and circulating progenitor cells in non-diabetic patients with essential hypertension: a comparative study between Azelnidipine and amlodipine on glucose tolerance and endothelial function - a crossover trial (AGENT). Cardiovasc Diabetol. 2011;10:79.

9. Trinder $P$. Determination of glucose in blood using glucose oxidase with an alternative oxygen receptor. Ann. Clin. Biochem. 1969;6:24-27.

10. Mathews DR, Hosker JP, Rudenski AS, et al. Homeostasis model assessment: Insulin resistance and beta-cell function from fasting plasma glucose and insulin concentration in man. Diabetologia. 1985; 28: 412-9.

11. Sowers JR, Epstein M, Frohlich ED. Diabetes, hypertension, and cardiovascular disease: an update. Hypertension. 2001; 37(4):1053-9.

12. Kurtz TW, Pravenec M. Antidiabetic mechanisms of angiotensin-converting enzyme inhibitors and angiotensin II receptor antagonists: beyond the renin angiotensin system. J Hypertens. 2004; 22(12):2253-61. 13. Ersoy C, Imamoglu S, Budak F, et al. Effect of amlodipine on insulin resistance \& tumor necrosis factoralpha levels in hypertensive obese type 2 diabetic patients. Indian J Med Res. 2004;120(5):481-8.

14. Bharati SM, Singh N. Effect of losartan and amlodipine on insulin sensitivity in non-diabetic hypertensive patients. IJBCP. 2016; 5 (1): 202-208.

15. Tian Z, Yan Y, Deng $S$, et al. Effect of valsartan on insulin resistance in patients with hypertension: a systematic review and meta-analysis. Int $\mathrm{J}$ Clin Exp Med. 2016;9(7):14047-14056.

16. Yusuf S, Teo KK, Pogue J, et al. Telmisartan, ramipril, or both in patients at high risk for vascular events. The New England Journal of Medicine. 2008;358:1547-59.

17. Rodriguez-Perez JC, Garcia-Bello MA, AnabitartePrieto $A$, et al. Anti-albuminuric effects of the angiotensin AT1 receptor blocker telmisartan in hypertensive patients. Clinical and experimental hypertension (New York, NY : 1993). 2011;33:506-10.

18. Stump CS, Hamilton MT, Sowers JR. Effect of antihypertensive agents on the development of type 2 diabetes mellitus. Mayo Clin Proc. 2006;81(6):796-806.

19. Jandeleit-Dahm KA, Tikellis C, Reid CM, et al. Why blockade of the renin-angiotensin system reduces the incidence of new-onset diabetes. J Hypertens. 2005; 23 : 463-473.

20. Wei $Y$, Sowers JR, Nistala R, et al. Angiotensin IIinduced NADPH oxidase activation impairs insulin signaling in skeletal muscle cells. J Biol Chem. 2006; 281: 35137-35146.

21. Manrique C, Lastra G, Gardner $M$, et al. The renin angiotensin aldosterone system in hypertension: roles of insulin resistance and oxidative stress. Med Clin North Am. 2009; 93: 569-582.

22. Schupp $M$, Janke $J$, Clasen $R$, et al. Angiotensin type 1 receptor blockers induce peroxisome proliferatoractivated receptor-gamma activity. Circulation. 2004; 109: 2054-2057. 